\title{
The importance of translaminar fracture toughness for the penetration impact behaviour of woven carbon/glass hybrid composites
}

\author{
Yentl Swolfs ${ }^{* 1,2}$, Yoran Geboes ${ }^{1}$, Larissa Gorbatikh ${ }^{1}$, Silvestre T. Pinho ${ }^{2}$ \\ ${ }^{1}$ Department of Materials Engineering, KU Leuven, Kasteelpark Arenberg 44 bus 2450, \\ Belgium \\ ${ }^{2}$ Department of Aeronautics, Imperial College London, South Kensington Campus, SW7 \\ 2AZ, London, United Kingdom
}

*Corresponding author: Y. Swolfs (yentl.swolfs@kuleuven.be), Tel.: 003216373616

\section{Abstract}

The impact resistance of fibre-reinforced composites is vital in many applications, and can be improved by exploiting synergies in fibre-hybridisation. These effects are however not sufficiently well understood in the literature. Penetration impact tests were hence performed on carbon/glass hybrids, and the results were linked to the flexural behaviour and translaminar fracture toughness. The results revealed large synergetic effects of up to $40 \%$ compared to the linear rule-of-mixtures. The results are also the first to reveal that creating a translaminar fracture surface can strongly contribute to the energy absorbed during penetration impact: $56 \%$ for an all-carbon fibre composite and $13 \%$ for an all-glass fibre composite. These results prove that strategies for maximising the translaminar fracture toughness can also be exploited to maximise the penetration impact resistance of fibre-hybrids. In carbon fibre composites in particular, ply blocking, using larger yarns and introducing micro-cuts should therefore increase the penetration impact resistance.

Keywords: A. Hybrid; A. Polymer-matrix composites (PMCs); B. Fracture toughness; B. Impact behaviour;

\section{Introduction}

The term ñfibre-hybridò composite applies to composites containing more than one type of reinforcement fibre [1]. These composites are a fast-growing class of composites, as they allow combining the benefits of both fibre types, while alleviating some of their drawbacks. The top layer of a carbon fibre composite can for example be replaced by a glass fibre layer to make the part more damage tolerant with minimal loss of stiffness and strength. Another common driver for fibre-hybridisation is cost reduction. This can, for example, be achieved by using the more expensive fibre type only in regions where it is needed the most, and using an inexpensive fibre type elsewhere. In general, the greater design freedom of fibre-hybrid composites will lead to more optimal designs.

The hybrid effect has been studied extensively in the literature [1-3]. With reference to the failure strain in tension, the hybrid effect is defined as the apparent increase in the initial failure strain of the low elongation fibre composite in the hybrid composite relative to the composite with only low elongation fibres. In general terms, the hybrid effect can be described as any deviation from a simple rule-of-mixtures [1]. Many authors found positive hybrid effects in hybrid composites [3-8]. The challenge of fibre-hybridisation lies in understanding, predicting and eventually optimising the hybrid effect and associated complex behaviours.

While the state of the art has greatly advanced since the start of fibre-hybridisation in highperformance composites $[9,10]$, the majority of the progress was achieved for tensile loading. 
Other, more complex loading conditions received less attention and are lacking a solid understanding. This is especially true for impact, as revealed by a recent review paper on fibrehybrid composites [1]. For example, shifting the carbon fibre layers more towards the middle layers in symmetric carbon/glass hybrids had varying effects on various impact-related parameters. While this shift increased the damaged area according to Naik et al. [11] and Sevkat et al. [12], it decreased according to González et al. [6]. Similarly, this shift deteriorated the compression-after-impact according to Kowsika and Mantena [13] and Naik et al. [11], whereas González et al. [6] found no effect. Following these publications, there is a strong need for developing a clear understanding of how the change in layup causes a change in performance.

While advanced finite element models for impact on composites have been developed [14-19], they have rarely been applied to fibre-hybrid composites [20,21]. As a consequence, the current state-of-the-art in impact on fibre-hybrid composites is mainly limited to visual observations rather than being governed by a general framework for understanding their behaviour. This paper aims to provide a better understanding of the penetration impact resistance of fibre-hybrid composites by linking it to the translaminar fracture toughness and flexural behaviour. It also presents one of the first translaminar fracture toughness results on fibre-hybrid composites.

\section{Materials and methods}

\subsection{Materials}

The properties of the fibres, yarns and fabrics are summarised in Table 1. Values with standard deviations were measured, whereas the others come from the respective data sheets or literature [22,23]. The carbon fibre weave consisted of HTA $6 \mathrm{~K}$ carbon fibres in a balanced twill $2 / 2$ architecture. The weave had 3.5 yarns/cm in both directions, resulting in an areal density of 285 $\mathrm{g} / \mathrm{m}^{2}$. A glass fibre weave was selected that also had a balanced twill $2 / 2$ architecture and that would yield a similar layer thickness. The chosen weave consisted of E-glass fibres with 6.8 yarns $/ \mathrm{cm}$, resulting in an areal density of $390 \mathrm{~g} / \mathrm{m}^{2}$. The resin was an EPIKOTE ${ }^{\mathrm{TM}}$ 828LVEL epoxy resin mixed with 1,2-diaminocyclohexane hardener in a 100/15.2 ratio. Previous measurements showed that this epoxy has a stiffness of $3 \mathrm{GPa}$, and the Poissonôs ratio was estimated to be 0.4 .

Table 1: Fibre, yarn and fabric properties.

\begin{tabular}{|c|c|c|}
\hline & Carbon fibre & Glass fibre \\
\hline Fibre type & HTA40 E13 & E-glass \\
\hline Density $\left(\mathrm{kg} / \mathrm{m}^{3}\right)$ & 1760 & 2560 \\
\hline Diameter $(\mu \mathrm{m})$ & 6 & $13 \pm 0.3$ \\
\hline Fibre longitudinal modulus $(\mathrm{GPa})$ & 238 & 78 \\
\hline Fibre transverse modulus $(\mathrm{GPa})$ & 15 & 78 \\
\hline Fibre in-plane Poissonô ratio $(-)$ & 0.25 & 0.22 \\
\hline Tensile strength $(\mathrm{MPa})$ & 3950 & - \\
\hline Elongation at break $(\%)$ & 1.7 & - \\
\hline Yarn K-count & 6000 & - \\
\hline Yarn linear density (tex) & 400 & $274 \pm 8.5$ \\
\hline Weave architecture & Twill $2 / 2$ & Twill $2 / 2$ \\
\hline Picks and yarns $\left(\right.$ yarns $\left./ \mathrm{cm}^{2}\right)$ & 3.5 & $6.8 \pm 0.1$ \\
\hline Fabric areal density $\left(\mathrm{g} / \mathrm{m}^{2}\right)$ & 285 & 390 \\
\hline
\end{tabular}




\subsection{Vacuum assisted resin infusion}

All plies were cut and stacked together aligned with the fibre directions of the weave. Panels were made with either 8 or 16 layers (see Table 2). The 8-layer panels were used for bending and impact tests, whereas the 16-layer panels were used for compact tension tests (see Table 2). After the layers were stacked, a peel ply and distribution medium were added to the top. For the 16 layers however, the peel ply and distribution medium were also added to the bottom to facilitate impregnation. The entire assembly was placed on a $5 \mathrm{~mm}$ thick aluminium plate, after which a vacuum bag was added on top. The assembly was placed on a hot plate to raise the impregnation temperature to $50^{\circ} \mathrm{C}$. The resin was mixed and then degassed for $15 \mathrm{~min}$, after which it was infused at a 0.99 bar vacuum pressure. After the entire layup was impregnated, the temperature was increased to $150^{\circ} \mathrm{C}$ and insulation material was added on top. After a 90 min cure cycle, the hot plate was switched off to cool to room temperature. Optical microscopy confirmed that the laminates were well impregnated with very limited porosities.

Different layups were manufactured and these are summarised in Table 2. The indicated variations in Table 2 and anywhere else in this paper refer to the $95 \%$ confidence intervals. The thickness values confirm that the carbon and glass layers have nearly the same layer thickness, thereby avoiding any thickness effects when changing the layup.

Table 2: Overview of the manufactured layups (C and G stand for the carbon and glass layer, respectively).

\begin{tabular}{|c|c|c|c|}
\hline Layup & $\begin{array}{l}\text { Volume fraction of glass } \\
\text { fibre composite }\end{array}$ & Thickness (mm) & Tested in: \\
\hline $\mathrm{C}_{8}$ & $0 \%$ & $2.33 \pm 0.04$ & \\
\hline$\left(\mathrm{C}_{3} \mathrm{G}\right)_{\mathrm{s}}$ & & $2.26+0.03$ & \\
\hline$\left(\mathrm{GC}_{3}\right)_{\mathrm{s}}$ & & $2.29+0.02$ & \\
\hline$\left(\mathrm{C}_{2} \mathrm{G}_{2}\right)_{\mathrm{s}}$ & & $2.29 \pm 0.02$ & \\
\hline$(\mathrm{CG})_{2 \mathrm{~s}}$ & & $2.31 \pm 0.01$ & \\
\hline$\left(\mathrm{G}_{2} \mathrm{C}_{2}\right)_{\mathrm{s}}$ & & $2.40 \pm 0.03$ & \\
\hline$(\mathrm{GC})_{2 \mathrm{~s}}$ & & $2.29 \pm 0.02$ & \\
\hline$\left(\mathrm{CG}_{3}\right)_{\mathrm{s}}$ & & $2.30 \pm 0.02$ & \\
\hline$\left(\mathrm{G}_{3} \mathrm{C}\right)_{\mathrm{s}}$ & & $2.28+0.02$ & \\
\hline $\mathrm{G}_{8}$ & $100 \%$ & $2.39 \pm 0.02$ & \\
\hline $\mathrm{C}_{16}$ & $0 \%$ & $4.41 \pm 0.03$ & \\
\hline$\left(\mathrm{G}_{4} \mathrm{C}_{4}\right)_{\mathrm{S}}$ & & $4.48+0.03$ & \\
\hline$(\mathrm{GC})_{4 \mathrm{~s}}$ & & $4.60 \pm 0.03$ & \\
\hline $\mathrm{G}_{16}$ & $100 \%$ & $4.72 \pm 0.05$ & \\
\hline
\end{tabular}

\subsection{Penetration impact tests}

Falling weight impact tests were performed on a Fractovis CEAST 6789 drop tower according to ISO 6603-2 [24]. The striker was hemispherical with a $20 \mathrm{kN}$ load cell in the tip and a 20 $\mathrm{mm}$ diameter. The drop height was $1 \mathrm{~m}$, resulting in an impact velocity of about $4.4 \mathrm{~m} / \mathrm{s}$. The total weight of the striker was $26.17 \mathrm{~kg}$, which ensured penetration in all samples. The specimens were cut to $100 \times 100 \mathrm{~mm}$ using a band saw and were clamped on a support ring with an inner/outer diameter of $40 / 60 \mathrm{~mm}$. A minimum of six specimens were tested for each configuration. The support ring was roughened to maximise friction and the total gripping force was $2800 \mathrm{~N}$. As the manufacturing process resulted in a smooth bottom surface and a rougher top surface, care was taken to always have the smooth surface facing upwards. 
Data reduction was performed by integrating the force-displacement diagram. The integration was stopped either when the load dropped below half the peak load or below zero the first time. These two measures will be referred to as r̃nalf peak methodò and ñfull methodò, respectively. It should be noted that the half peak method is the data reduction recommended by the ISO 6603-2 standard [24]. Fibre-hybrid composites, however, often show a rather long tail in the force-displacement diagram $[25,26]$. Since the full method may be more appropriate here, results for both methods will be shown. The penetration impact resistance was normalised by the sample thickness to obtain values in $\mathrm{J} / \mathrm{mm}$ units.

\subsection{Flexural tests}

Three point-bending specimens were cut using a diamond saw to ensure smooth edges. They were tested according to ASTM D7264M [27] on an Instron 4467 machine with a $1 \mathrm{kN}$ load cell. The nominal dimensions were 10x100x2.3 mm with a support span of $80 \mathrm{~mm}$. The loading nose and support rollers all had a diameter of $10 \mathrm{~mm}$. The loading nose moved at a displacement rate of $4.54 \mathrm{~mm} / \mathrm{min}$, corresponding to a $1 \% / \mathrm{min}$ nominal strain rate. Five specimens were tested for each configuration. The manufacturing resulted in a smooth bottom surface and a rougher top surface. To improve consistency and to reduce the likelihood of compressive failure, the samples were tested with the smooth side facing the loading nose. The test was monitored with a camera to track the damage progression.

\subsection{Compact tension tests}

Compact tension tests were performed on an Instron 5969 with a $50 \mathrm{kN}$ load cell. The doubletapered specimen design, described in Blanco et al. [28], was used. The outer specimen dimensions were $70 \times 90 \mathrm{~mm}$ with an initial crack length of either 20 or $30 \mathrm{~mm}$. The overall shape was water jet cut and the initial notch was applied using a circular saw with a thickness of $3 \mathrm{~mm}$ and sharp tip. The notch tip was then sharpened using a thin razor blade. A minimum of five specimens were tested for each configuration.

Initial tests revealed that the specimens were prone to buckling before fracture initiation. To prevent buckling, a steel anti-buckling guide was clamped on the top and bottom of the specimen using four screws that were loosely tightened by hand. This guide was sufficient to prevent buckling and it was verified that the guide did not interfere with the load and displacement data. This was confirmed by interrupting a test and removing the guide near failure initiation, which did not result in a noticeable change in the load. All tested specimens with a $20 \mathrm{~mm}$ notch yielded a suitable failure, apart from the $\left(\mathrm{C}_{8}\right)_{\mathrm{s}}$ layup. For this layup, the initial tests revealed failure occurred around the loading holes. To achieve a suitable failure, a longer initial notch of 30 instead of $20 \mathrm{~mm}$ was machined in the $\left(\mathrm{C}_{8}\right)_{\mathrm{s}}$ specimens.

Data reduction was performed using the compliance calibration method with finite element models [29]. Table 3 summarised the engineering constants used in the finite element model. These constants were obtained from WiseTex-TexComp calculations [30,31] in combination with the flexural modulus obtained from the experiments. The translaminar fracture toughness was calculated as the average toughness value over the plateau region of the R-curve. The initial rising part of the R-curve was avoided as our main interest was in the toughness for crack propagation. The last $10 \%$ of the crack growth was also avoided to prevent compressive failure at the back from interfering with the data. 
Table 3: Engineering constants of the plies, which were the output of the WiseTex-TexComp calculations and the input for the compliance calibration finite element model.

\begin{tabular}{|l|c|c|c|c|c|c|}
\hline & $\mathrm{E}_{1}(\mathrm{GPa})$ & $\mathrm{E}_{2}(\mathrm{GPa})$ & $3_{12}(-)$ & $\mathrm{G}_{12}(\mathrm{GPa})$ & $\mathrm{G}_{13}(\mathrm{GPa})$ & $\mathrm{G}_{23}(\mathrm{GPa})$ \\
\hline Carbon fibre & 54.92 & 54.92 & 0.026 & 2.18 & 1.10 & 1.10 \\
\hline Glass fibre ply & 22.94 & 22.94 & 0.052 & 1.55 & 1.06 & 1.06 \\
\hline
\end{tabular}

\subsection{Microscopy}

Scanning electron microscopy (SEM) was performed on a Hitachi S-3700N machine to perform fractography, and measure the width of fractured material. The applied voltage was $10 \mathrm{kV}$. The specimens were coated with gold to ensure good conductivity and inhibit specimen charging. A penetrated sample was cut straight through the impact location using a diamond saw. This sample was embedded in an epoxy resin and subsequently ground and polished down to a particle size of $1 \mu \mathrm{m}$. The sample for Figure 8 was taken from a $\mathrm{C}_{8}$ sample, and prepared the same way. Both samples were examined at a $4 x$ and 10x magnification in a Leica DMILM optical light microscope equipped with a Zeiss Axiocam ERc5s. The impacted sample was used to measure the delaminated length. Combining this length with the visual observation that the delaminated area was nearly circular (see Figure 10b), permitted calculating the overall delaminated area.

\section{Results}

\subsection{Impact behaviour}

The penetration impact resistance results are summarised in Figures 1-2 and Table 4. The results for both the half peak and full method are presented, as they revealed a different trend.

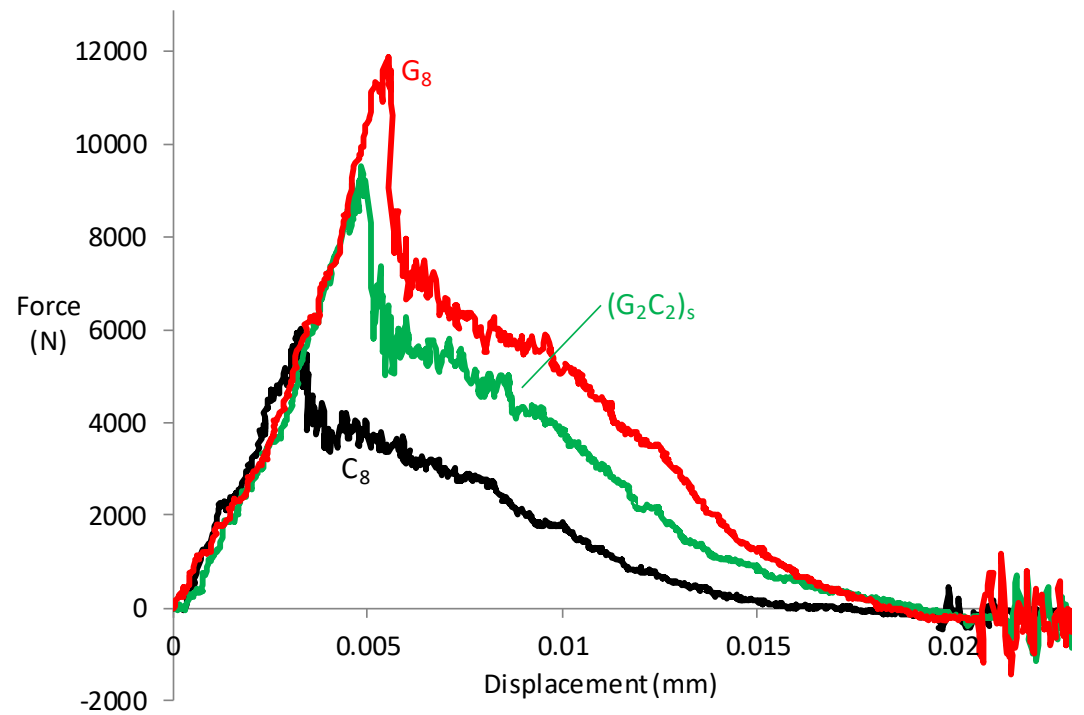

Figure 1: Representative force-displacement diagrams for the penetration impact tests on the two reference composites and one hybrid composite. 
Table 4: Overview of the mechanical properties of carbon/glass hybrid composites.

\begin{tabular}{|c|c|c|c|c|}
\hline \multirow[t]{2}{*}{ Layup } & \multicolumn{2}{|c|}{$\begin{array}{l}\text { Penetration impact } \\
\text { resistance }(\mathrm{J} / \mathrm{mm})\end{array}$} & \multirow{2}{*}{$\begin{array}{l}\text { Area underneath } \\
\text { flexural diagram } \\
\qquad\left(\mathrm{MJ} / \mathrm{m}^{3}\right)\end{array}$} & \multirow{2}{*}{$\begin{array}{l}\text { Translaminar } \\
\text { fracture toughness } \\
\qquad\left(\mathrm{kJ} / \mathrm{m}^{2}\right)\end{array}$} \\
\hline & Half peak & Full & & \\
\hline $\mathrm{C}_{8}$ & $9.6 \pm 0.8$ & $15.2 \pm 0.7$ & $8.0 \pm 0.8$ & - \\
\hline$\left(\mathrm{C}_{3} \mathrm{G}\right)_{\mathrm{s}}$ & $12.2+0.8$ & $20.6 \pm 0.7$ & $9.8 \pm 2.4$ & - \\
\hline$\left(\mathrm{GC}_{3}\right)_{\mathrm{s}}$ & $16.2 \pm 0.6$ & $22.0 \pm 0.3$ & $10.8 \pm 1.1$ & - \\
\hline$\left(\mathrm{C}_{2} \mathrm{G}_{2}\right)_{\mathrm{s}}$ & $14.6 \pm 0.6$ & $24.5 \pm 0.9$ & $10.0 \pm 1.4$ & - \\
\hline$(\mathrm{CG})_{2 \mathrm{~s}}$ & $13.1 \pm 0.9$ & $24.0 \pm 0.6$ & $11.9 \pm 1.4$ & - \\
\hline$\left(\mathrm{G}_{2} \mathrm{C}_{2}\right)_{\mathrm{s}}$ & $17.2 \pm 1.1$ & $25.0 \pm 0.8$ & $12.9 \pm 1.5$ & - \\
\hline$(\mathrm{GC})_{2 \mathrm{~s}}$ & $16.8 \pm 1.3$ & $25.8 \pm 0.4$ & $10.6 \pm 1.8$ & - \\
\hline$\left(\mathrm{CG}_{3}\right)_{\mathrm{s}}$ & $15.2 \pm 0.3$ & $27.8 \pm 0.4$ & $12.3 \pm 1.4$ & - \\
\hline$\left(\mathrm{G}_{3} \mathrm{C}\right)_{\mathrm{s}}$ & $20.1+1.1$ & $28.5 \pm 0.5$ & $12.0 \pm 0.9$ & - \\
\hline $\mathrm{G}_{8}$ & $17.7 \pm 1.1$ & $29.7 \pm 0.7$ & $11.3 \pm 1.0$ & - \\
\hline $\mathrm{C}_{16}$ & - & - & - & $171 \pm 17$ \\
\hline$\left(\mathrm{G}_{4} \mathrm{C}_{4}\right)_{\mathrm{s}}$ & - & - & - & $142 \pm 5$ \\
\hline$(\mathrm{GC})_{4 \mathrm{~s}}$ & - & - & - & $104+3$ \\
\hline $\mathrm{G}_{16}$ & - & - & - & $75+1$ \\
\hline
\end{tabular}

As expected, the glass fibre reference composites $\left(\mathrm{G}_{4}\right)_{\mathrm{s}}$ performed better than the carbon fibre reference composite $\left(\mathrm{C}_{4}\right)_{\mathrm{s}}$ according to both reduction methods. The difference was larger for the full method (see Figure 2b) than the half peak method (see Figure 2a), indicating that the propagation part of the dissipated energy is larger for the glass than for the carbon fibre composite. 

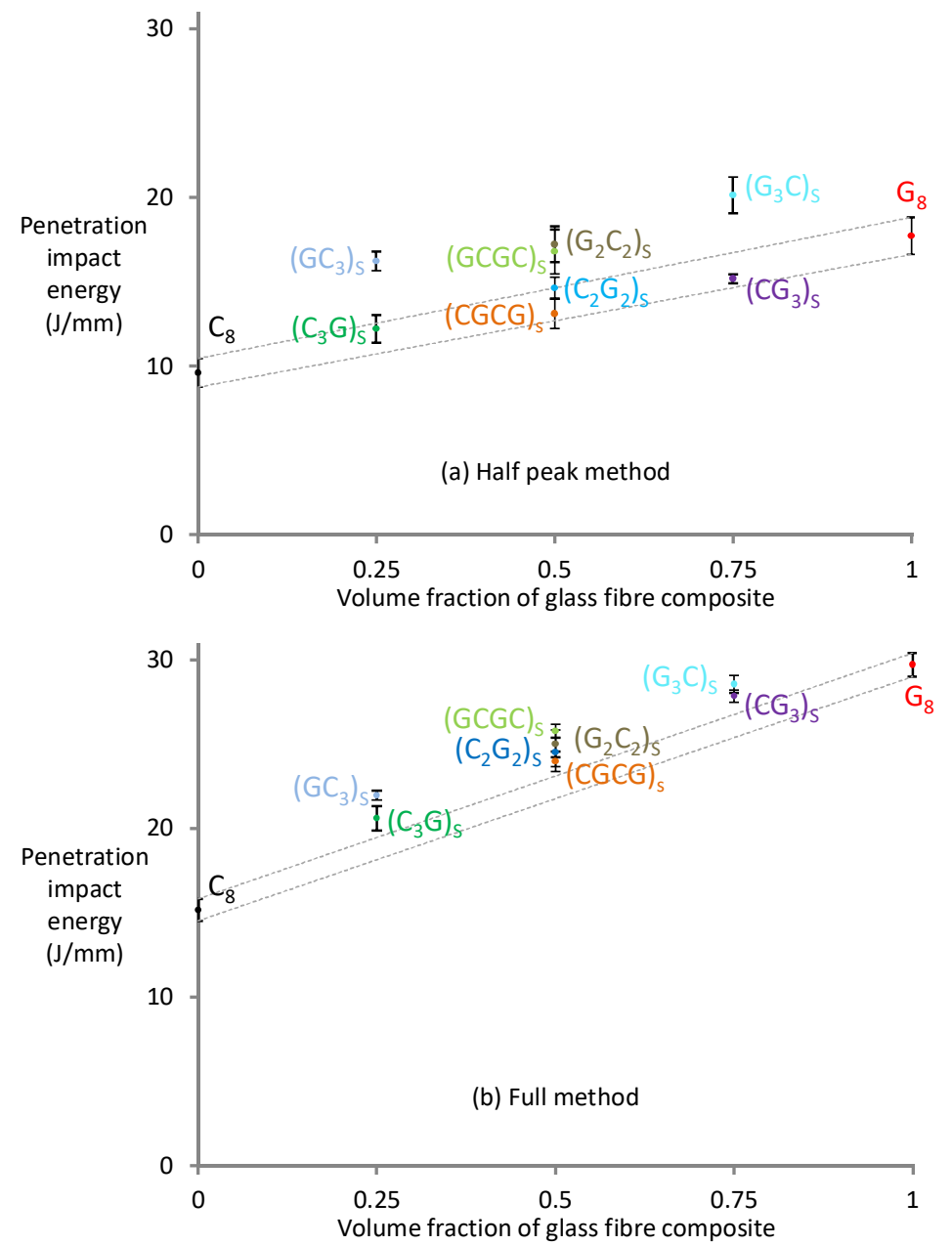

Figure 2: Penetration impact energy of carbon/glass hybrids as a function of the volume fraction of glass fibre composite: (a) half peak method and (b) full method. The dashed lines indicate the interpolated $95 \%$ confidence interval for the two reference composites.

The hybrid composites display synergetic effects of up to $40 \%$ compared to the rule-ofmixtures. For the half peak method, all hybrids with glass on the outside performed significantly better than the linear rule-of-mixtures (as indicated by the dashed lines). All hybrids with carbon on the outside, however, performed approximately according to the rule of mixtures. Remarkably, the $\left(\mathrm{G}_{3} \mathrm{C}\right)_{\mathrm{s}}$ performed better than the $\left(\mathrm{G}_{4}\right)_{\mathrm{s}}$ layups with a p-value of $0.5 \%$ for the half peak method. This is a true synergy, as this hybrid performed better than either of its two constituent composite materials according to the data reduction method recommended by the ISO 6603-2 standard. Similarly, the $\left(\mathrm{GC}_{3}\right)_{\mathrm{s}}$ layup performed $69 \%$ better than the $\mathrm{C}_{8}$-layup and only $9 \%$ worse than the $\mathrm{G}_{8}$ layup. It is striking that replacing just two of the eight layers can lead to such large increases.

\subsection{Flexural behaviour}

The first step to understanding the penetration impact resistance results in Figure 2 is to better understand the flexural behaviour. Even though impacting a clamped specimen results in a complex combination of tension and flexure, the impact results did reveal the importance of the layup (see Figure 2). It therefore seems likely that understanding the flexural behaviour is more important than understanding the tensile behaviour. 
Figure 3 presents representative flexural diagrams of all specimen configurations. The reference composites $\mathrm{C}_{8}$ and $\mathrm{G}_{8}$ both displayed a nearly complete failure when the maximum stress was reached. The same is true for the hybrid layups $\left(\mathrm{C}_{3} \mathrm{G}\right)_{\mathrm{s}},\left(\mathrm{G}_{3} \mathrm{C}\right)_{\mathrm{s}}$ and $\left(\mathrm{G}_{2} \mathrm{C}_{2}\right)_{\mathrm{s}}$. This is attributed to the fact that $\left(\mathrm{C}_{3} \mathrm{G}\right)_{\mathrm{s}}$ is similar to $\mathrm{C}_{8}$ and $\left(\mathrm{G}_{3} \mathrm{C}\right)_{\mathrm{s}}$ and $\left(\mathrm{G}_{2} \mathrm{C}_{2}\right)_{\mathrm{s}}$ to $\mathrm{G}_{8}$. The only difference is that the inner layers are replaced, but those layers do not contribute much to the flexural properties. All the other hybrid layups displayed a stepwise failure behaviour.

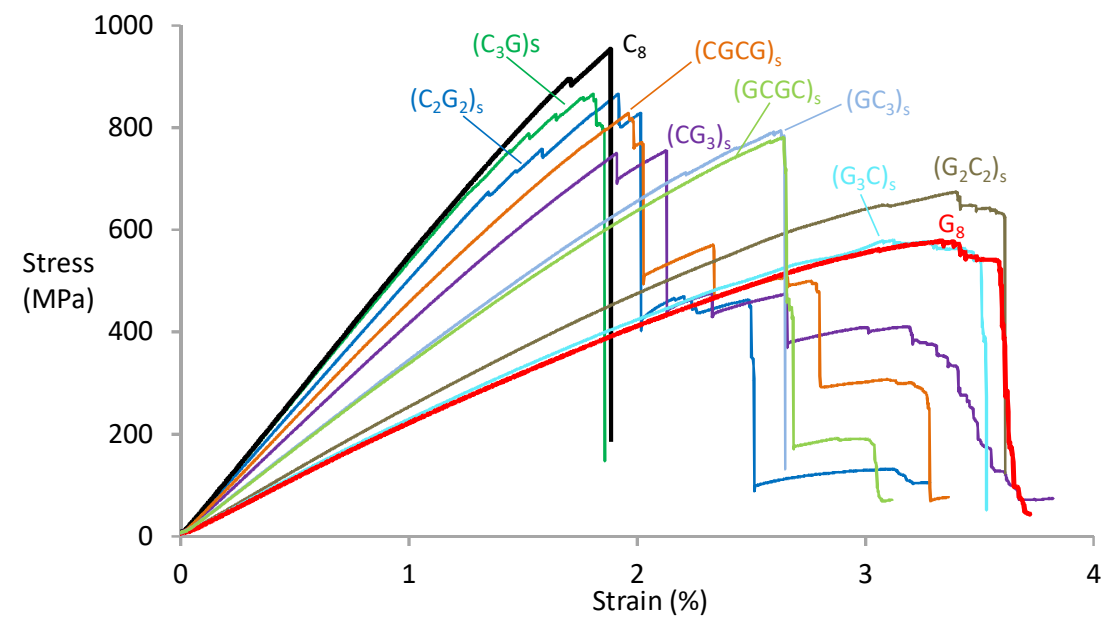

Figure 3: The reference specimens and some hybrids revealed a nearly complete failure when the maximum stress was reached. Other hybrids however showed a stepwise failure. One representative diagram is displayed for each layup.

Failure progression analyses were performed based on the recorded images of the test. The carbon fibre reference $\mathrm{C}_{8}$ revealed no damage prior to final failure. The final failure occurred so rapidly that the images could not capture whether failure initiated on the compressive or the tensile side. For the glass fibre reference $\mathrm{G}_{8}$, failure initiated in compression, which caused the stress to level off prior to the large stress drop (see Figure 3). Strong reductions in stress only occurred when the bottom glass plies failed in tension.

The failure progression of a $\left(\mathrm{C}_{2} \mathrm{G}_{2}\right)_{\mathrm{s}}$ hybrid is displayed in Figure 4 . The stress vs. strain diagram is shown in Figure 4a, where the points highlighted correspond to the images in Figure 4b-f. After elastic loading (see Figure 4b), damage started by compressive failure of the top carbon fibre layer, accompanied by buckling (see Figure 4c). In the next step, the second carbon fibre layer on the compressive side also failed and buckled (see Figure 4d). Upon further loading, partial tensile failure of the bottom carbon fibre ply appeared (see Figure 4e). Next, the second carbon fibre ply on the bottom also failed in tension (see Figure 4f). Afterwards, the central glass fibre plies continued to carry the load, and the test was stopped at this point. It should be noted that the damage in flexure is localised under the loading nose, and occurs over a length of about $5 \mathrm{~mm}$. Given the small length scale, it could be argued whether the damage between the plies (see Figure 4d-f) can rightfully be called delaminations. 

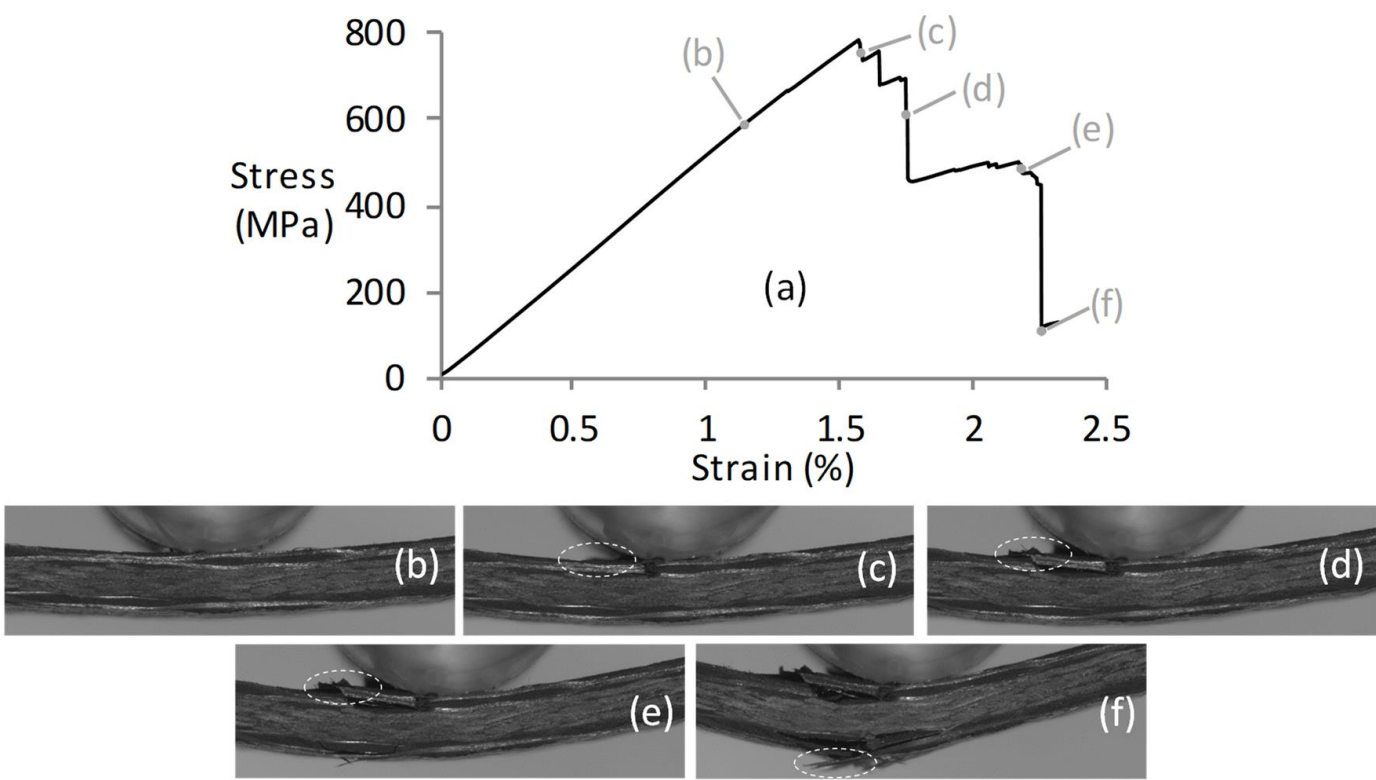

Figure 4: Failure progression of a $\left(\mathrm{C}_{2} \mathrm{G}_{2}\right)_{\mathrm{s}}$ hybrid: (a) stress-strain diagram, (b) before failure, (c) compressive failure of the first layer underneath the loading nose, (d) compressive failure of the second layer underneath the loading nose, (e) tensile failure of the outer carbon fibre layer and (f) tensile failure of the second carbon fibre layer on the bottom.

The stepwise behaviour of the hybrid specimens indicates a more gradual failure behaviour, which links well with the large difference between the full and half peak method in Figure 2. Such difference indicates that the propagation part dissipates a significant fraction of the impact energy. The absorbed energy in flexure can be approximated by integrating the flexural diagrams. The results revealed strong synergetic effects (see Figure 5 and Table 4) with several hybrids having larger average area than both reference composites. Fibre-hybridisation can therefore cause a more gradual failure, which leads to increased energy dissipation. The optimal layup is however not clear, as no clear correlations emerge from Figure 5. Placing the carbon fibres on the inside was better in some cases, but worse in others: $\left(\mathrm{C}_{2} \mathrm{G}_{2}\right)_{\mathrm{s}}$ was for example worse than $\left(\mathrm{G}_{2} \mathrm{C}_{2}\right)_{\mathrm{s}}$, whereas $(\mathrm{CGCG})_{\mathrm{s}}$ is better than $(\mathrm{GCGC})_{\mathrm{s}}$.

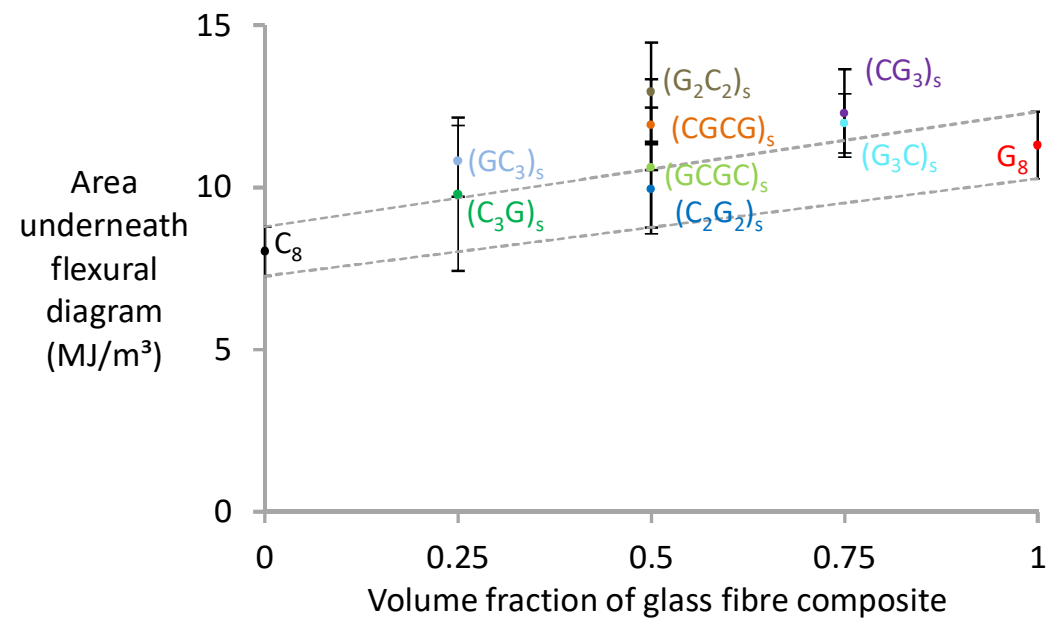

Figure 5: The energy underneath the flexural diagram reveals positive synergetic effects for most hybrids. The dashed lines indicate the interpolated $95 \%$ confidence interval for the two reference composites. 
Analysing the flexural behaviour is useful to identify changes in the fracture behaviour, but the analysis is complicated by the complex loading and the scatter of the results. The key conclusion is however that the flexural behaviour did not reveal any consistent layup-dependent trends. The flexural behaviour is therefore insufficient to explain the lay-up dependent trends in the penetration impact resistance.

\subsection{Translaminar fracture toughness}

The translaminar fracture toughness test was adapted to fibre-reinforced composites by Pinho et al. [32]. It is important to note that this test allows stable translaminar crack growth, which is crucial for measuring translaminar toughness to crack propagation. There is extensive literature on translaminar fracture toughness for carbon fibre-reinforced composites, but data on glass fibre-reinforced composites is scarce and relatively recent [33-36]. The compact tension test is only rarely applied to woven composites due to undesirable failure mechanisms $[28,33,35,37]$.

The carbon fibre composite was tougher than the glass fibre composite (see Figures 6-7 and Table 4). This is in line with the results of Ortega et al. [33,36], which are the only two publications that reported translaminar fracture toughness values of both carbon and glass fibre composites. Ortega et al. also measured a higher toughness value for their carbon fibre composites than for their glass fibre composites. In their work, however, the carbon fibre layers were more than $50 \%$ thicker than the glass fibre layers and the picks and ends of the carbon fibre fabric were about 2.3 times lower than for the glass fibre fabric. Given the well-known ply thickness effect on translaminar fracture toughness [38,39], this makes the interpretation of their results significantly more difficult.

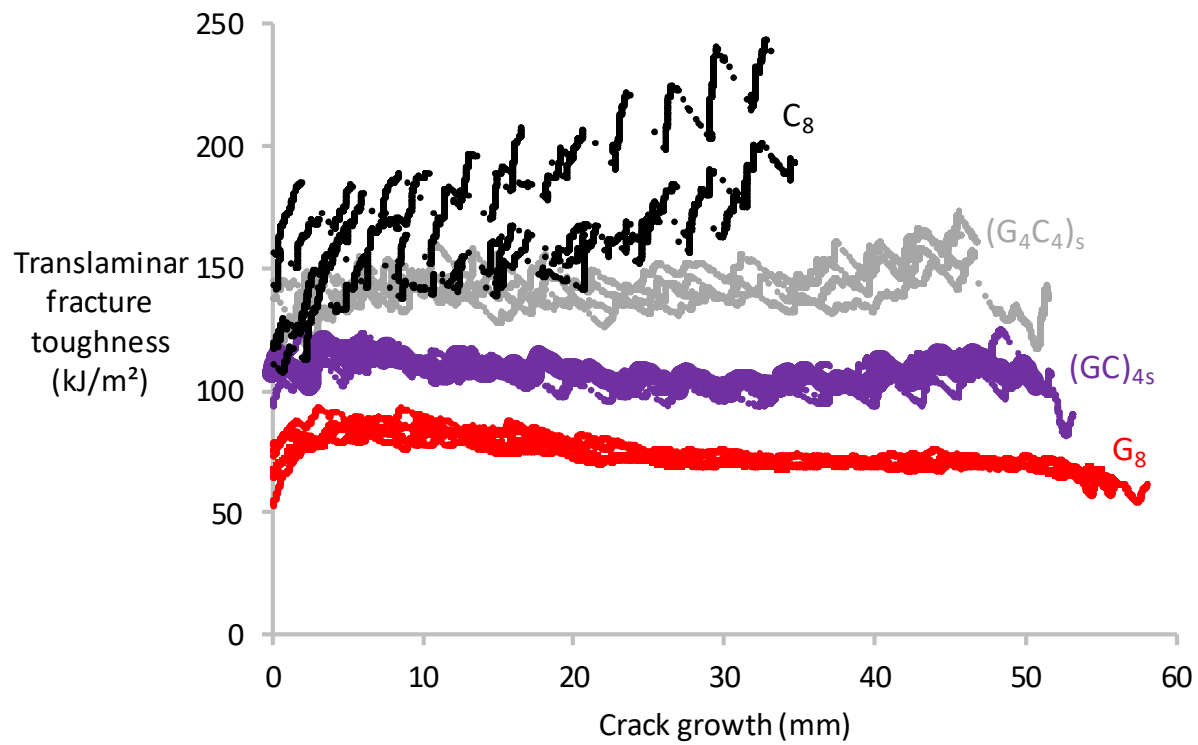

Figure 6: R-curves for the hybrid composites and its reference composites. Note that the initial rising part as well as the last $10 \%$ of the $R$-curve was not taken into account in calculating the average translaminar fracture toughness. 


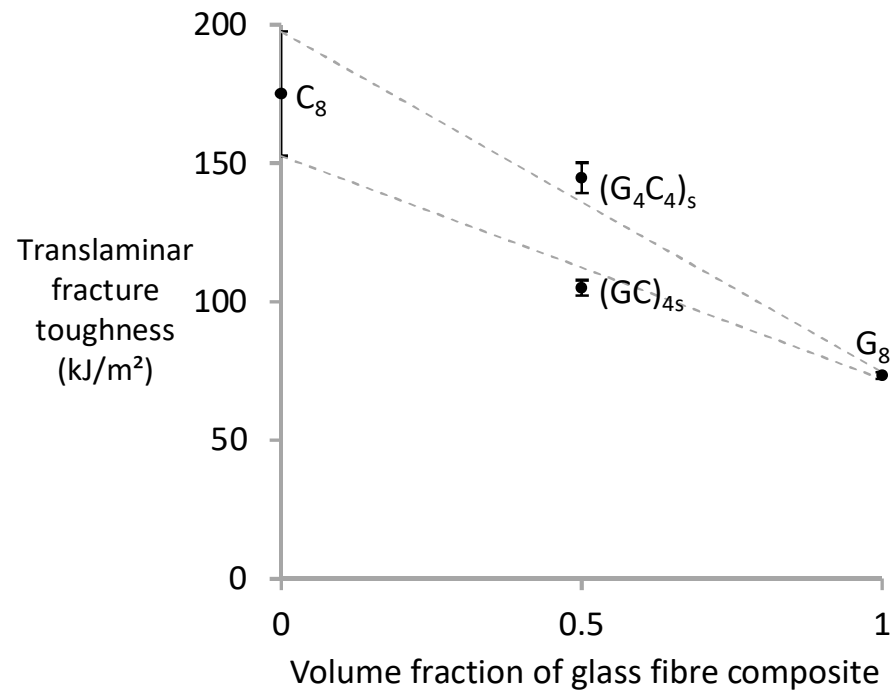

Figure 7: The translaminar fracture toughness of two hybrids and the reference composites. The dashed lines indicate the interpolated $95 \%$ confidence interval for the two reference composites.

The fact that carbon fibre composites were tougher than glass fibre ones in Figure 7 cannot be attributed to the intrinsic fracture toughness of the fibres: this toughness contribution has been proved to be very limited [40,41]. Instead, the translaminar fracture toughness is controlled by fibre pull-out and debonding [29,39]. The higher toughness of $\mathrm{C}_{8}$ relative to $\mathrm{G}_{8}$ is hence attributed to the fact that the carbon fibre yarns are much larger than the glass fibre ones. This size difference can be seen from the picks and ends, which are 3.5 yarns $/ \mathrm{cm}$ for the carbon fibre weave and 6.8 yarns/cm for the glass fibre one. Additionally, each carbon fibre yarn contains about 6000 fibres, whereas a glass fibre yarn contains an estimated 820 fibres. The results here hence agree with Pimenta and Pinho [39], who proved that larger bundles with more fibres lead to higher translaminar fracture toughness values. This is because such systems create longer pull-out lengths, which require more energy to be pulled apart.

Both hybrid layups deviated significantly from the linear rule-of-mixtures. $\left(\mathrm{G}_{4} \mathrm{C}_{4}\right)_{\mathrm{S}}$ showed a positive hybrid effect, whereas $(\mathrm{GC})_{4 \mathrm{~s}}$ showed a negative hybrid effect. It should be noted that the high toughness of $\left(\mathrm{G}_{4} \mathrm{C}_{4}\right)_{\mathrm{s}}$ cannot be attributed to the traditional ply thickness effect described in the literature $[38,39,42,43]$. This ply thickness effect is attributed to the higher energy absorption in thicker plies caused by the longer pull-out lengths that can be achieved compared to thinner plies. Such effects have mainly been demonstrated for cross-ply laminates with unidirectional plies [38,42]. From a mechanical viewpoint, the same size effect should also exist in woven composites, albeit with some minor alterations. The $90^{\circ}$ yarns in the weave essentially isolate the $0^{\circ}$ yarns from each other. The isolation is however not complete, as the $0^{\circ}$ yarns in one woven ply are still partially in contact with the $0^{\circ}$ in the neighbouring ply.

The hypothesis to explain the hybrid effect for translaminar fracture toughness is based on the imperfect isolation by the $90^{\circ}$ yarns. If two woven plies are next to each other, some yarns in both plies act together, allowing them to create longer pull-outs. Figure 8 illustrates the random nature of a woven microstructure, with some yarns connected to each other and others isolated from each other. The connected yarns create a size effect: the laminate toughness is increased by allowing longer pull-outs to develop. In contrast, if a carbon fibre ply is placed next to a glass fibre ply, the glass fibre ply will tend to reduce the pull-out lengths of the carbon fibre yarn. This effect resulted in reduced overall pull-out lengths for $(\mathrm{GC})_{4 \mathrm{~s}}$ when compared to $\left(\mathrm{G}_{4} \mathrm{C}_{4}\right)_{\mathrm{s}}$, because $(\mathrm{GC})_{4 \mathrm{~s}}$ has more glass/carbon interfaces. 


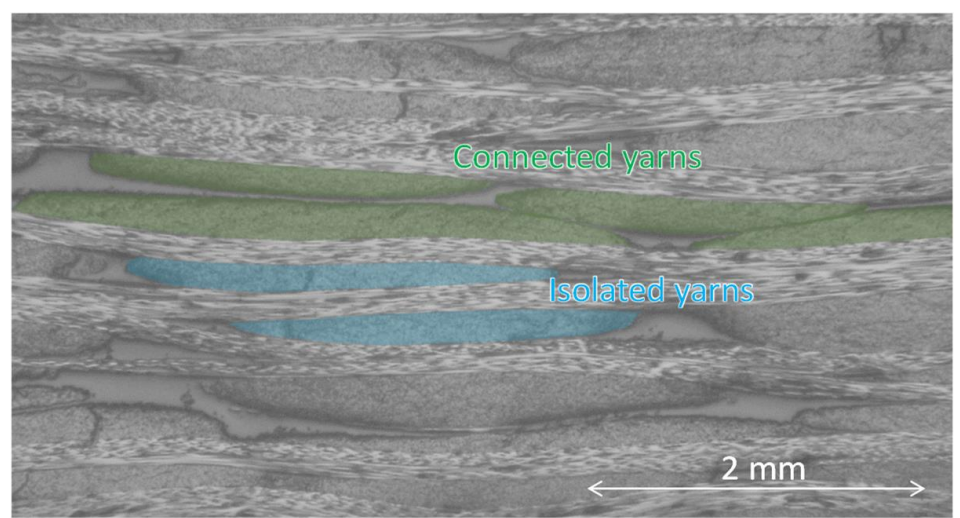

Figure 8: Some of the yarns in a woven composite are connected, whereas others are isolated. This microscopy image was taken from $\mathrm{C}_{8}$.

Fractographic observations confirmed the above hypothesis: $\mathrm{C}_{8}$ (see Figure $9 \mathrm{a}$ ) showed pullout lengths of 2-4 mm, whereas they were 0.5-1.5 $\mathrm{mm}_{\text {for }} \mathrm{G}_{8}$ (see Figure $9 \mathrm{~b}$ ) and 0.5-2.5 mm for $\left(\mathrm{G}_{4} \mathrm{C}_{4}\right)_{\mathrm{s}}$ (see Figure 9d). The pull-out lengths for $(\mathrm{GC})_{4 \mathrm{~s}}$ were however more difficult to measure (see Figure 9c). The middle seemed to have pull-out lengths similar to $\mathrm{C}_{8}$, whereas the rest of the specimen displayed shorter pull-out lengths. Figure $9 \mathrm{c}$ hence confirms the proposed hypothesis, as $(\mathrm{GC})_{4 \mathrm{~s}}$ has two carbon fibre plies next to each other in the middle. Those two plies should lead to pull-out lengths similar to those in $\mathrm{C}_{8}$. In the other layers however, the glass fibre plies restrict the pull-out lengths of the carbon fibre yarns.
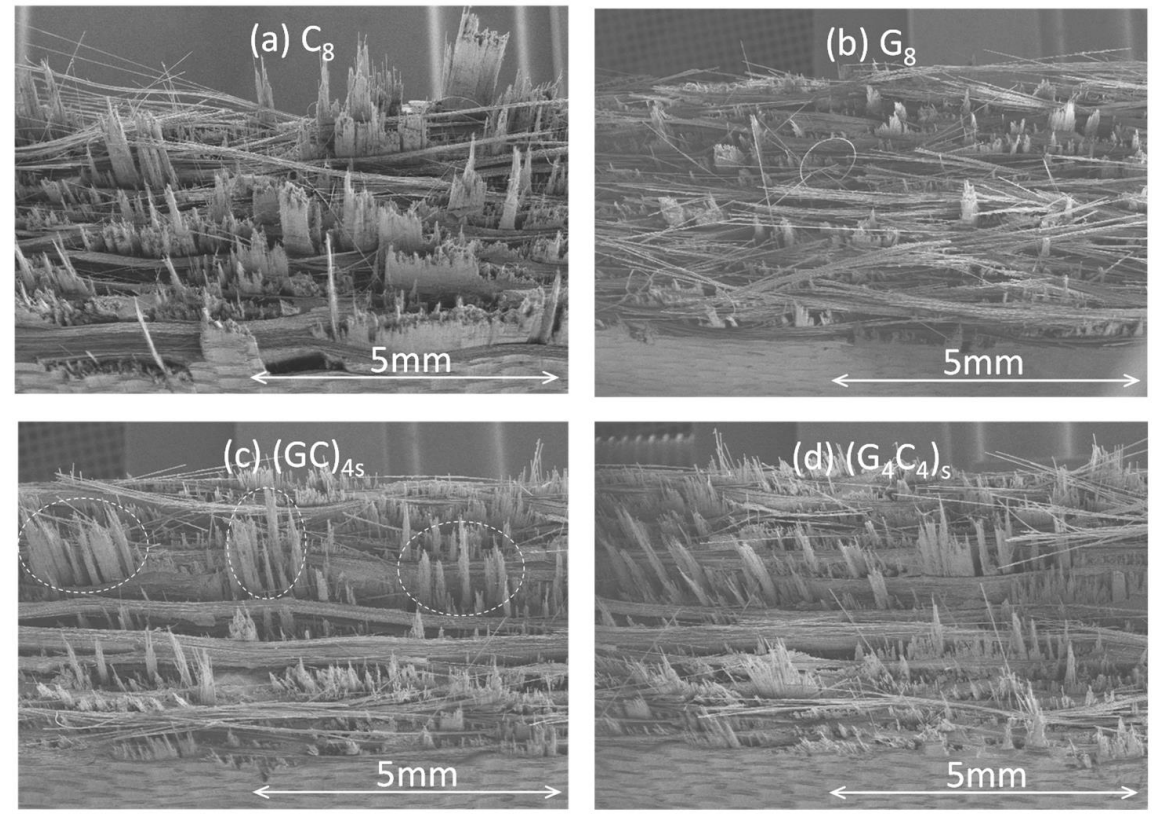

Figure 9: SEM images of (a) $C_{8}$, (b) $G_{8}$, (c) $(G C)_{4 s}$ and (d) $\left(G_{4} C_{4}\right)_{s}$. The circles in (c) highlight the longer pull-out lengths in the middle of the specimen.

It should be noted that the Ortega et al. [36] tested three different interlayer hybrid layups based on woven fabrics. Their results are, however, more difficult to interpret, as they had large differences in layer thickness. Additionally, they placed their balanced fabrics at angles of $0^{\circ}$, $45^{\circ}$ and $60^{\circ}$. Interactions between yarns at different angles are more complex to analyse. Ortega et al. did find a positive synergy for one of their layups, but it is unclear whether that synergy was statistically significant. They even stated that ñthe mixing theory roughly predicts the toughness of the hybrid laminatesò [36]. 


\section{Overall discussion}

Fundamentally understanding the penetration impact resistance of hybrid composites is a challenging task. The presented results however shed new light on the underlying mechanisms. Fibre-hybridisation causes a more gradual failure in flexure, which can lead to increased energy absorption during failure. This effect is however insufficient to explain why placing glass fibre on the outside improves the penetration impact resistance. While the translaminar fracture toughness results could not explain this finding either, it did point to an additional mechanism. Blocking plies of the same fibre type together increased the translaminar fracture toughness. Figure 2a seems to confirm that blocked plies lead to larger penetration impact resistance: $\left(\mathrm{G}_{2} \mathrm{C}_{2}\right)_{\mathrm{s}}$ is tougher than $(\mathrm{GCGC})_{\mathrm{s}}$ and $\left(\mathrm{C}_{2} \mathrm{G}_{2}\right)_{\mathrm{s}}$ is tougher than $(\mathrm{CGCG})_{\mathrm{s}}$. This statement, however, does not hold for the full method in Figure $2 \mathrm{~b}$. The simple analysis based on the half peak method in Figure 2a therefore would have led to an incorrect, or to say the least, oversimplified conclusion.

Another interesting feature arises when the penetration impact resistance values are analysed in more detail. The average translaminar fracture toughness of the $(\mathrm{GC})_{4 \mathrm{~s}}$ and $\left(\mathrm{G}_{4} \mathrm{C}_{4}\right)_{\mathrm{s}}$ hybrids is approximately $125 \mathrm{~kJ} / \mathrm{m}^{2}$. All impact samples fractured in a ñ+ò-shaped pattern with a height and width of $25 \mathrm{~mm}$ (see Figure 10). This is also true for the glass fibre reference composite (see Figure 10b), even though those samples also revealed significant damage outside the ñ+ò. This fracture pattern leads to a total of $50 \mathrm{~mm}$ of material that was fractured. Using these values, the energy required to penetrate a 50/50 carbon/glass hybrid sample can be estimated to be 6.3 $\mathrm{J}$ per $\mathrm{mm}$ of thickness $\left(2 \times 25 \mathrm{~mm} \times 125 \mathrm{~kJ} / \mathrm{m}^{2}\right)$. This value is about $40 \%$ and $25 \%$ of the measured values according to the half peak and full method, respectively (see Table 4). The energy dissipated by delamination can also be estimated. Siegfried et al. [44] measured a mode II interlaminar fracture toughness of $1038 \mathrm{~J} / \mathrm{m}^{2}$ for the same carbon fibre/epoxy system. The total delaminated surface of one hybrid layup $\left(\mathrm{G}_{2} \mathrm{C}_{2}\right)_{\mathrm{s}}$ was measured to be $5700 \mathrm{~mm}^{2}$ based on optical microscopy. This leads to an estimated energy dissipation of $2.5 \mathrm{~J}$ per mm of thickness, if we assume that the mode II interlaminar fracture toughness of the G-C and G-G delamination is the same as for the C-C delamination. These estimates would indicate that the translaminar fracture toughness plays a larger role than the delaminations.

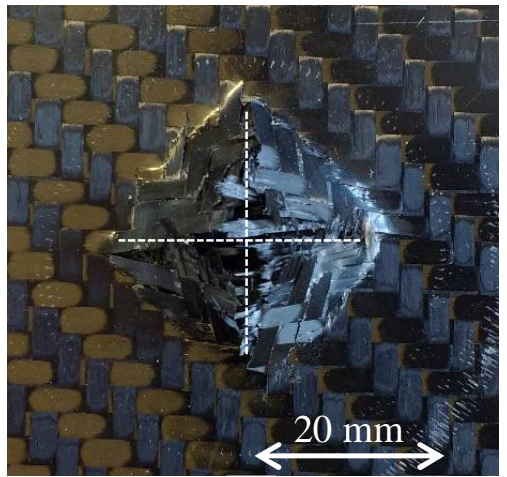

(a)

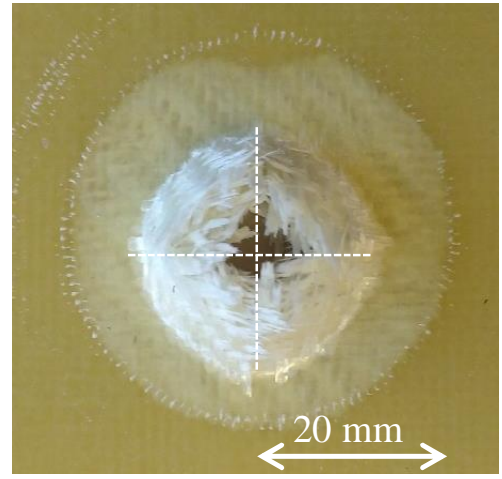

(b)

Figure 10: The +-shaped pattern in the penetrated samples: (a) $C_{8}$ and (b) $G_{8}$. The white dashed lines indicate the main fracturing region.

During translaminar fracture, the energy is dissipated mostly by debonding and pull-out. Both features are substantially more prominent in the translaminar fracture surface of glass than in carbon fibre composites (see Figure 9a and b), and hence one may expect a higher translaminar fracture toughness for glass fibre composites. In the woven material set studied here however, 
this is not the case. Note that translaminar fracture is size-dependent, but the ply thicknesses were the same for glass and carbon, which suggests that the yarn dimensions may be the dominating feature for the size effect in woven composites. Interestingly, the higher translaminar fracture toughness of carbon fibre/epoxy was not reflected in a higher penetration impact resistance. Although unproven, this is likely due to the higher stiffness of the carbon fibres causing a more localised deformation. Note that the calculation in the previous paragraph would lead to an estimated penetration impact resistance of $8.5 \pm 0.8 \mathrm{~J} / \mathrm{mm}(2 \times 25 \mathrm{~mm} \times 0.171$ $\left.\mathrm{J} / \mathrm{mm}^{2}\right)$ for $\mathrm{C}_{8}$ and $3.8 \pm 0.1 \mathrm{~J} / \mathrm{mm}\left(2 \times 25 \mathrm{~mm} \times 0.075 \mathrm{~J} / \mathrm{mm}^{2}\right)$ for $\mathrm{G}_{8}$. These values should be compared to the measured ones, which were $15.2 \pm 0.7 \mathrm{~J} / \mathrm{mm}$ and $29.7 \pm 0.7 \mathrm{~J} / \mathrm{mm}$, respectively. The translaminar fracture toughness hence contributes $56 \%$ of the energy for $\mathrm{C}_{8}$, whereas this is only $13 \%$ for $\mathrm{G}_{8}$. This large difference indicates that $\mathrm{G}_{8}$ dissipates a significant amount of energy through other means, such as delaminations and friction with the striker. The larger delaminated area of $\mathrm{G}_{8}$ relative to $\mathrm{C}_{8}$ can be clearly observed in Figure 10.

\section{Conclusion}

The results established the importance of the translaminar fracture toughness for the penetration impact resistance of carbon and glass composites and their hybrids. The main conclusions are:

- The penetration impact resistance can benefit significantly from synergetic effects: the hybrids performed up to $40 \%$ better than the linear rule-of-mixtures.

- Hybrid composites reveal a more gradual flexural behaviour than non-hybrid composites, which can help to explain their more gradual behaviour in impact. No clear layup-dependent trends in the area underneath the flexural diagram were found.

- Blocked plies led to a higher translaminar fracture toughness, and such plies also led to a higher penetration impact resistance according to the half peak method. For the full method, this did not lead to higher penetration impact resistance.

- A significant fraction of the impact energy is dissipated by creating the translaminar fracture surface: $56 \%$ for the carbon fibre composites and $13 \%$ for the glass fibre composites.

These results open new avenues for increasing the penetration impact resistance through strategies developed for increasing the translaminar fracture toughness: ply blocking [38], using larger yarns and introducing micro-cuts [45].

\section{Acknowledgements}

The authors acknowledge the support of the European Commission for the Marie Skø̆dowskaCurie Individual European Fellowship ñHierToughò for YS. YS acknowledges the support of FWO Flanders for his postdoctoral fellowship. STP acknowledges EPSRC for his ñNextGenò fellowship (EP/M002500/1).

\section{References}

[1] Swolfs Y, Gorbatikh L, Verpoest I. Fibre hybridisation in polymer composites: a review. Composites Part A: Applied Science and Manufacturing. 2014;67:181-200.

[2] Kretsis G. A review of the tensile, compressive, flexural and shear properties of hybrid fibrereinforced plastics. Composites. 1987;18(1):13-23.

[3] Wisnom MR, Czel G, Swolfs Y, Jalalvand M, Gorbatikh L, Verpoest I. Hybrid effects in thin ply carbon/glass unidirectional laminates: accurate experimental determination and prediction. Composites Part A: Applied Science and Manufacturing. 2016;88:131-139. 
[4] Swolfs Y, McMeeking RM, Gorbatikh L, Verpoest I. The effect of fibre dispersion on initial failure strain and cluster development in unidirectional carbon/glass hybrid composites. Composites Part A: Applied Science and Manufacturing. 2015;69:279-287.

[5] Swolfs Y, Verpoest I, Gorbatikh L. Maximising the hybrid effect in unidirectional hybrid composites. Materials \& Design. 2016;93:39-45.

[6] González EV, Maimí P, Sainz de Aja JR, Cruz P, Camanho PP. Effects of interply hybridization on the damage resistance and tolerance of composite laminates. Composite Structures. 2014;108:319-331.

[7] Sarasini F, Tirillò J, Valente M, Valente T, Cioffi S, Iannace S, et al. Effect of Basalt Fibre Hybridization on The Impact Behaviour Under Low Impact Velocity of Glass/Basalt Woven Fabric/Epoxy Resin Composites. Composites Part A: Applied Science and Manufacturing. 2013;47:109-123.

[8] De Rosa IM, Marra F, Pulci G, Santulli C, Sarasini F, Tirillo J, et al. Post-impact mechanical characterisation of E-glass/basalt woven fabric interply hybrid laminates. Express Polymer Letters. 2011;5(5):449-459.

[9] Phillips LN. The hybrid effect - does it exist? Composites. 1976;7(1):7-8.

[10] Hayashi T. On the improvement of mechanical properties of composites by hybrid composition. Proc 8th Intl Reinforced Plastics Conference. 1972:149-152.

[11] Naik NK, Ramasimha R, Arya H, Prabhu SV, ShamaRao N. Impact response and damage tolerance characteristics of glassï carbon/epoxy hybrid composite plates. Composites Part B: Engineering. 2001;32(7):565-574.

[12] Sevkat E, Liaw B, Delale F, Raju BB. Drop-weight impact of plain-woven hybrid glassï graphite/toughened epoxy composites. Composites Part A: Applied Science and Manufacturing. 2009;40(8):1090-1110.

[13] Kowsika MV, Mantena PR. Static and low-velocity impact response characteristics of pultruded hybrid glass-graphite/epoxy composite beams. Journal of Thermoplastic Composite Materials. 1999;12(2):121-132.

[14] Hou JP, Petrinic N, Ruiz C, Hallett SR. Prediction of impact damage in composite plates. Composites Science and Technology. 2000;60(2):273-281.

[15] Xiao S, Chen P, Ye Q. Prediction of damage area in laminated composite plates subjected to low velocity impact. Composites Science and Technology. 2014;98:51-56.

[16] Hou JP, Petrinic N, Ruiz C. A delamination criterion for laminated composites under lowvelocity impact. Composites Science and Technology. 2001;61(14):2069-2074.

[17] Li CF, Hu N, Yin YJ, Sekine H, Fukunaga H. Low-velocity impact-induced damage of continuous fiber-reinforced composite laminates. Part I. An FEM numerical model. Composites Part A: Applied Science and Manufacturing. 2002;33(8):1055-1062.

[18] González EV, Maimí P, Camanho PP, Turon A, Mayugo JA. Simulation of drop-weight impact and compression after impact tests on composite laminates. Composite Structures. 2012;94(11):3364-3378.

[19] Shi Y, Swait T, Soutis C. Modelling damage evolution in composite laminates subjected to low velocity impact. Composite Structures. 2012;94(9):2902-2913.

[20] Yang B, Wang Z, Zhou L, Zhang J, Liang W. Experimental and numerical investigation of interply hybrid composites based on woven fabrics and PCBT resin subjected to low-velocity impact. Composite Structures. 2015;132:464-476.

[21] Manikandan P, Chai GB. A layer-wise behavioral study of metal based interply hybrid composites under low velocity impact load. Composite Structures. 2014;117:17-31.

[22] Shindo A. Polyacrylonitrile (PAN)-based carbon fibers. In: Kelly A, Zweben C, Chou TW, editors. Comprehensive composite materials, vol. 1.01, Amsterdam: Elsevier; 2000. p. 1-33.

[23] Dwight DW. Glass fiber reinforcements. In: Kelly A, Zweben C, Chou TW, editors. Comprehensive composite materials, vol. 1.08, Amsterdam: Elsevier; 2000. p. 1-31. 
[24] ISO 6603-2 Plastics - Determination of puncture impact behaviour of rigid plastics - Part 2: Instrumented testing, Geneva, Switzerland, ISO, 2000.

[25] Pegoretti A, Fabbri E, Migliaresi C, Pilati F. Intraply and interply hybrid composites based on E-glass and poly(vinyl alcohol) woven fabrics: tensile and impact properties. Polymer International. 2004;53(9):1290-1297.

[26] Swolfs Y, Shi J, Meerten Y, Hine P, Ward I, Verpoest I, et al. The importance of bonding in intralayer carbon fibre/self-reinforced polypropylene hybrid composites. Composites Part A: Applied Science and Manufacturing. 2015;76:299-308.

[27] ASTM D7264M-07 - Standard Test Method for Flexural Properties of Polymer Matrix Composite Materials, Philadelphia, USA, ASTM, 2007.

[28] Blanco N, Trias D, Pinho ST, Robinson P. Intralaminar fracture toughness characterisation of woven composite laminates. Part I: Design and analysis of a compact tension (CT) specimen. Engineering Fracture Mechanics. 2014;131:349-360.

[29] Laffan MJ, Pinho ST, Robinson P, McMillan AJ. Translaminar fracture toughness testing of composites: A review. Polymer Testing. 2012;31(3):481-489.

[30] Lomov SV, Verpoest I, Cichosz J, Hahn C, Ivanov DS, Verleye B. Meso-level textile composites simulations: Open data exchange and scripting. Journal of Composite Materials. 2014;48(5):621-637.

[31] Verpoest I, Lomov SV. Virtual textile composites software WiseTex: Integration with micro-mechanical, permeability and structural analysis. Composites Science and Technology. 2005;65(15ї 16):2563-2574.

[32] Pinho ST, Robinson P, Iannucci L. Fracture toughness of the tensile and compressive fibre failure modes in laminated composites. Composites Science and Technology. 2006;66(13):2069-2079.

[33] Ortega A, Maimí P, González EV, Ripoll L. Compact tension specimen for orthotropic materials. Composites Part A: Applied Science and Manufacturing. 2014;63:85-93.

[34] Mohammed Y, Hassan MK, Abu El-Ainin H, Hashem AM. Effect of stacking sequence and geometric scaling on the brittleness number of glass fiber composite laminate with stress raiser. Science and Engineering of Composite Materials. 2014;21(2):281-288.

[35] Rokbi M, Osmani H, Benseddiq N, Imad A. On experimental investigation of failure process of woven-fabric composites. Composites Science and Technology. 2011;71(11):13751384.

[36] Ortega A, Maimí P, González EV, Sainz de Aja JR, de la Escalera FM, Cruz P. Translaminar fracture toughness of interply hybrid laminates under tensile and compressive loads. Composites Science and Technology. 2017;143:1-12.

[37] Blanco N, Trias D, Pinho ST, Robinson P. Intralaminar fracture toughness characterisation of woven composite laminates. Part II: Experimental characterisation. Engineering Fracture Mechanics. 2014;131:361-370.

[38] Teixeira RF, Pinho ST, Robinson P. Thickness-dependence of the translaminar fracture toughness: Experimental study using thin-ply composites. Composites Part A: Applied Science and Manufacturing. 2016;90:33-44.

[39] Pimenta S, Pinho ST. An analytical model for the translaminar fracture toughness of fibre composites with stochastic quasi-fractal fracture surfaces. Journal of the Mechanics and Physics of Solids. 2014;66(0):78-102.

[40] Honjo K. Fracture toughness of PAN-based carbon fibers estimated from strengthï mirror size relation. Carbon. 2003;41(5):979-984.

[41] Tanaka F, Okabe T, Okuda H, Kinloch IA, Young RJ. Factors Controlling the Strength of Carbon Fibres in Tension. Composites Part A: Applied Science and Manufacturing. 2014;57:88-94. 
[42] Laffan MJ, Pinho ST, Robinson P, Iannucci L. Measurement of the in situ ply fracture toughness associated with mode I fibre tensile failure in FRP. Part II: Size and lay-up effects. Composites Science and Technology. 2010;70(4):614-621.

[43] Li X, Hallett SR, Wisnom MR, Zobeiry N, Vaziri R, Poursartip A. Experimental study of damage propagation in Over-height Compact Tension tests. Composites Part A: Applied Science and Manufacturing. 2009;40(12):1891-1899.

[44] Siegfried M, Tola C, Claes M, Lomov SV, Verpoest I, Gorbatikh L. Impact and residual after impact properties of carbon fiber/epoxy composites modified with carbon nanotubes. Composite Structures. 2014;111:488-496.

[45] Bullegas G, Pinho ST, Pimenta S. Engineering the translaminar fracture behaviour of thinply composites. Composites Science and Technology. 2016. 